\title{
Knockdown of LI-cadherin alters expression of matrix metalloproteinase- 2 and -9 and galectin-3
}

\author{
QIONGFANG YU ${ }^{1}$, WEI SHEN ${ }^{2}$, HUANGYAN ZHOU $^{3}$, WEIGUO DONG $^{4}$ and DIAN GAO ${ }^{3}$ \\ Departments of ${ }^{1}$ Gastroenterology and Hepatology, and ${ }^{2}$ Gastrointestinal Surgery, Second Affiliated Hospital of \\ Nanchang University, Nanchang, Jiangxi 330006; ${ }^{3}$ Department of Pathogen Biology and Immunology, \\ Medical College of Nanchang University, Nanchang, Jiangxi 330006; ${ }^{4}$ Department of Gastroenterology \\ and Hepatology, Renmin Hospital of Wuhan University, Wuhan, Hubei 430060, P.R. China
}

Received July 9, 2015; Accepted March 10, 2016

DOI: $10.3892 / \mathrm{mmr} .2016 .5069$

\begin{abstract}
Liver-intestine cadherin (LI-cadherin), a novel member of the cadherin family, has been associated with the ability of a tumor to acquire an aggressive phenotype in several types of cancer. However, the exact function of LI-cadherin in the process of tumor invasion and metastasis remains predominantly unknown. To explore the effect of LI-cadherin on the regulation of matrix metalloproteinase-2 (MMP-2), MMP-9 and galectin-3 in LoVo human colorectal cancer cells, a RNA interference technique was applied to suppress the expression of LI-cadherin. Subsequently, the mRNA levels and activities of MMP-2 and -9 were analyzed by semi-quantitative reverse transcription-polymerase chain reaction and gelatin zymography, respectively. Additionally, the protein expression level of galectin-3 was determined by western blot analysis. The results of the present study demonstrated that short hairpin RNA (shRNA)-silencing of LI-cadherin significantly increased the mRNA levels and activities of MMP-2 and -9, and significantly reduced the protein levels of galectin- 3 in LoVo cells compared with control shRNA $(\mathrm{P}<0.05)$. These data indicate that knockdown of LI-cadherin facilitates the invasion of cancer cells by degrading extracellular matrix components via activation of MMP-2 and -9 , and increases cancer cell adhesion and migration via altered expression of galectin-3. This suggests that LI-cadherin serves an important role in the invasion and metastasis of colorectal cancer, and may be used as a potential therapeutic target.
\end{abstract}

Correspondence to: Dr Dian Gao, Department of Pathogen Biology and Immunology, Medical College of Nanchang University, 461 Bayi Road, Nanchang, Jiangxi 330006, P.R. China

E-mail: gaodian@ncu.edu.cn

Key words: LI-cadherin, galectin-3, matrix metalloproteinase-2, matrix metalloproteinase-9

\section{Introduction}

Cell adhesion is crucial during the development and adult life of multicellular organisms. There are principally two types of adhesion: Cell-cell adhesion; and cell-extracellular matrix (ECM) adhesion. The canonical receptors for cell-cell adhesion are cadherins (1). Cadherins are a multi-member glycoprotein family of transmembrane $\mathrm{Ca}^{2+}$-dependent adhesion molecules, which maintain tissue structure in normal and pathological settings $(2,3)$. They are major contributors to cell-cell adhesion. Numerous cadherin superfamily members have been previously identified and these are comprised of four different subfamilies (classical, desmosomal, atypical and protocadherins) (4). Distinct members of the cadherin family are important for morphogenesis during development, formation of junctional complexes, induction of the polarized cell type, development of cell-cell associations and the invasion of tumor cells (5).

Liver-intestine cadherin (LI-cadherin), also termed cadherin-17, is expressed in fetal livers and the gastrointestinal tract during embryogenesis as one member of the 7D-cadherin superfamily (6). LI-cadherin is often upregulated in certain types of cancer, including hepatocellular carcinoma, gastric, ductal pancreatic and colorectal cancer, however, it has not been reported to be expressed in brain tumors or blood malignancies (7). LI-cadherin has been observed to be expressed in $96 \%$ of tumor samples and is regarded as a useful diagnostic marker for adenocarcinomas of the digestive system (8). Compared with classical cadherins, including E-, N- and P-cadherin, LI-cadherin possesses several unique features (9). For example, it has seven extracellular cadherin domains, whereas classical cadherins have five cadherin repeats. Additionally, LI-cadherin has a short cytoplasmic domain composed of 20 amino acids, which shares no homology with the corresponding regions of classical cadherins, such as E-cadherin, which binds catenin proteins through their cytoplasmic domains to initiate signaling cascades. Although LI-cadherin is able to mediate $\mathrm{Ca}^{2+}$-dependent cell-cell adhesion (10), the difference in structure causes the adhesive function of LI-cadherin to be independent of any interaction with catenins, the actin cytoskeleton or other cytoplasmic components. The adhesive mechanism of LI-cadherin remains unclear. 
Previous studies have demonstrated that LI-cadherin is associated with colorectal carcinoma (11), gastric cancer (12-16), ductal adenocarcinoma of the pancreas (17) and hepatocellular carcinoma (18-23). Furthermore, the expression level of LI-cadherin is associated with lymph node metastasis, advanced pTNM stage, early tumor recurrence and poor overall survival $(15,16,24,25)$. Together, these previous studies indicate that LI-cadherin is associated with the ability of tumor cells to acquire an aggressive phenotype in several types of cancer. However, the exact mechanisms of LI-cadherin in the development of cancer remain unclear.

Galectin-3, a member of the $\beta$-galactoside-binding lectin family, is involved in several biological processes, including tumor cell proliferation, differentiation, angiogenesis, adhesion, motility, invasion, cancer progression and metastasis (26). Interaction of galectin-3 with adhesion and signaling receptors has been demonstrated to promote tumor cell migration. For example, galectin-3 binding to $\mathrm{N}$-cadherin destabilizes cell-cell junctions by increasing the turnover of $\mathrm{N}$-cadherin and other glycoconjugates, which may increase cell migration (27). Whether LI-cadherin exhibits a similar function via binding galectin-3 remains unclear. Additionally, a previous study demonstrated that galectin-3 is cleaved by members of the matrix metalloproteinase (MMP) family of enzymes. The 72-kDa (gelatinase A, MMP-2) and 92-kDa (gelatinase B, MMP-9) proteinases cleave galactin-3 to generate a $22-\mathrm{kDa}$ fragment containing the carbohydrate recognition domain and a $9-\mathrm{kDa}$ fragment comprising of the amino terminal of galectin-3. Thus, galectin-3 is considered as a substrate for human MMP-2 and -9 (28). It is possible that galectin-3, MMP-2 and MMP-3 are important regulating molecules in the LI-cadherin signaling pathway.

In the current study, to classify the role of LI-cadherin in regulating MMP-2, MMP3 and galectin-3 in colorectal cancer cells, an RNA interference strategy was employed to specifically knockdown LI-cadherin in LoVo cells. The results of the present study demonstrate that a reduction in the galectin-3 expression levels is associated with the increased expression of MMP-2 and MMP-9, which is mediated by LI-cadherin.

\section{Materials and methods}

Cell lines and cell culture. Derivation of the pU6-LI-cadherin-short hairpin RNA (shRNA)-transfected (Shanghai Genechem Co., Ltd., Shanghai, China) LoVo cell (American Type Culture Collection, Manassas, VA, USA) clone was performed as previously described (29). The pU6-LI-cadherin-shRNA-transfected and pU6-control-shRNA-transfected LoVo cell clones were maintained in Dulbecco's modified Eagle's medium (GE Healthcare Life Sciences, Logan, UT, USA) supplemented with $10 \%$ fetal calf serum (ExCell, Shanghai, China) and G418 (350 $\mu \mathrm{g} / \mathrm{ml})$ (Gibco; Thermo Fisher Scientific, Inc., Waltham, MA, USA).

Semi-quantitative reverse transcription-polymerase chain reaction $(R T-P C R)$. Total RNA was extracted using TRIzol reagent (Invitrogen; Thermo Fisher Scientific, Inc.), then $1 \mu \mathrm{g}$ RNA was reverse transcribed using the RevertAid First Strand
cDNA Synthesis kit (Fermentas; Thermo Fisher Scientific, Inc., Pittsburgh, PA, USA) according to the manufacturer's instructions. RT-PCR was performed using standard methodology and Ex Taq DNA polymerase and dNTPs were purchased from Takara Biotechnology Co., Ltd., (Dalian, China). Primers were designed according to the sequences of MMP-2 (GenBank accession no. NM_004530), MMP-9 (GenBank accession no. NM_004994) and $\beta$-actin (GenBank accession no. NM_001101). The primers used for MMP-2, MMP-9 and $\beta$-actin were as follows: MMP-2, forward 5'-CCA TCACTATGTGGGCTG-3', reverse 5'-TGCTGGCTGCCT TAGAAC-3' (168 bp); MMP-9, forward 5'-TTGACAGCG ACAAGAAGT-3', reverse 5'-AGTAGTGGCCGTAGAAGG-3' (483 bp); and $\beta$-actin, forward 5'-AAAGACCTGTACGCC AACA-3', reverse 5'-GGAGCAATGATCTTGATCTTC-3' (125 bp). The PCR was conducted on an S1000 ${ }^{\mathrm{TM}}$ Thermal Cycler (Bio-Rad, Hercules, California, USA) and the cycling conditions were as follows: For MMP-2 and $\beta$-actin, $94^{\circ} \mathrm{C}$ for $5 \mathrm{~min}, 30$ cycles of $94^{\circ} \mathrm{C}$ for $30 \mathrm{sec}, 58^{\circ} \mathrm{C}$ for $30 \mathrm{sec}$ and $72^{\circ} \mathrm{C}$ for $30 \mathrm{sec}$, followed by an additional extension step of $10 \mathrm{~min}$ at $72^{\circ} \mathrm{C}$; and for MMP-9, $94^{\circ} \mathrm{C}$ for $5 \mathrm{~min}, 30$ cycles of $94^{\circ} \mathrm{C}$ for $30 \mathrm{sec}, 50^{\circ} \mathrm{C}$ for $30 \mathrm{sec}$, and $72^{\circ} \mathrm{C}$ for $30 \mathrm{sec}$, followed by an additional extension step of $10 \mathrm{~min}$ at $72^{\circ} \mathrm{C}$. The RT-PCR products were separated by electrophoresis in a $1.5 \%$ agarose gel and visualized using ethidium bromide (Tiangen, Beijing, China) and a 2UV Transilluminator (LM-26E; UVP, Inc., Upland, CA, USA). The expression ratio (MMP-2/ $\beta$-actin and MMP-9/ $\beta$-actin) measured by densitometry (Gel-Pro Analyzer 4.0, Media Cybernetics, Inc., Rockville, MD, USA) was used to evaluate the mRNA levels of the genes. The mRNA level of each sample was detected following at least two independent experiments.

Western blot analysis. LoVo cells were lysed in radioimmunoprecipitation assay buffer (Beyotime Institute of Biotechnology, Beijing, China) containing $50 \mathrm{mM}$ Tris-HCl, $150 \mathrm{mM} \mathrm{NaCl}, 1 \mathrm{mM}$ ethylenediaminetetraacetic acid, $1 \mathrm{mM}$ sodium orthovanadate, $1 \mathrm{mM} \mathrm{NaF}, 1 \% \mathrm{NP} 40$, and $0.25 \%$ sodium deoxycholate supplemented with $1 \mathrm{mM}$ phenylmethylsulfonyl fluoride and quantified using the DC Protein Assay kit (Bio-Rad Laboratories, Inc., Hercules, CA, USA). Equal amounts of proteins from each sample were applied to a $10 \%$ sodium dodecyl sulfate (SDS) polyacrylamide gel (Beijing Solarbio Science \& Technology Co., Ltd., Beijing, China) and transferred to a polyvinylidene difluoride membrane (EMD Millipore, Billerica, MA, USA). The membranes were blocked in $5 \%$ non-fat milk and incubated at $4{ }^{\circ} \mathrm{C}$ overnight with diluted rabbit polyclonal anti-galectin-3 (1:1,000; cat. no. sc-20157; Santa Cruz Biotechnology, Inc., Dallas, TX, USA) or mouse monoclonal anti- $\beta$-actin $(1: 3,000$; cat. no. sc-47778; Santa Cruz Biotechnology, Inc.) primary antibodies, followed by incubation with horseradish peroxidase (HRP)-conjugated goat anti-rabbit IgG (cat. no. ZDR-5403; ZSGB-Bio, Beijing, China). Immunoreactive bands were visualized using Immobilon Western Chemiluminescent HRP Substrate (EMD Millipore) and signals were developed on X-ray film (Kodak, Rochester, NY, USA). The expression ratio (galectin-3/ $\beta$-actin) as measured by densitometry (Gel-Pro Analyzer 4.0, Media Cybernetics, Inc.) was used to evaluate protein levels. 
A
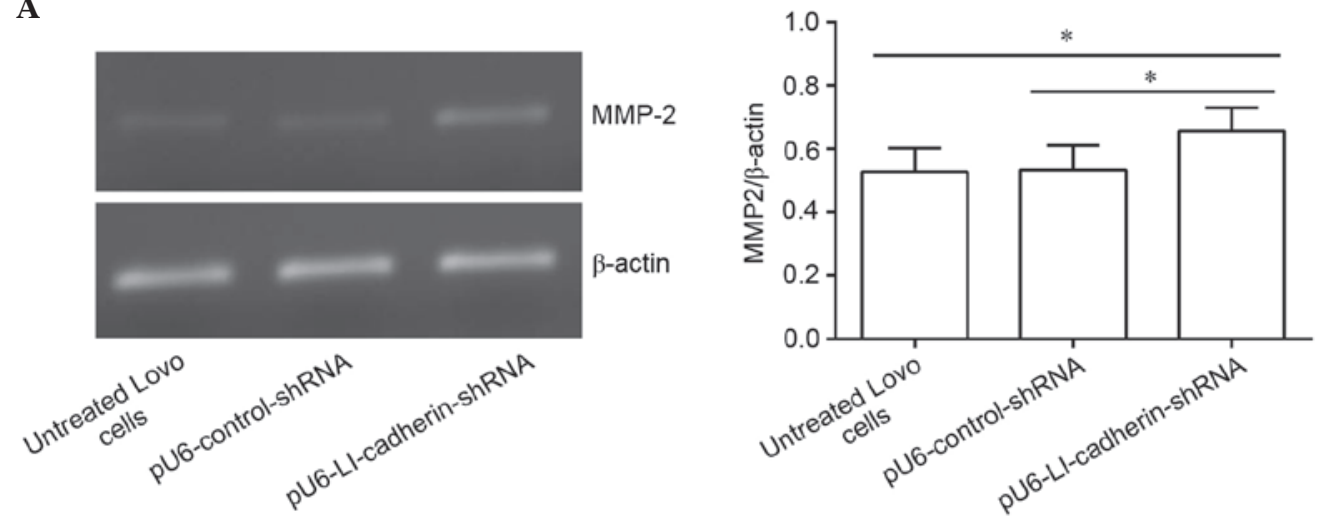

B
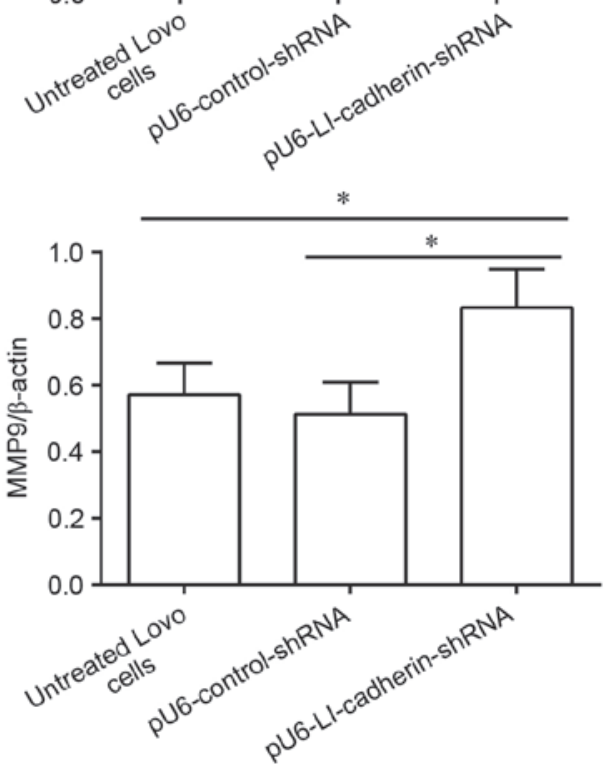

Figure 1. Effects of pU6-LI-cadherin-shRNA on mRNA transcript levels of MMP-2 and MMP-9 in LoVo cells. Semi-quantitative reverse transcription-polymerase chain reaction was performed to assess the mRNA levels of (A) MMP-2 and (B) MMP-9. $\beta$-actin was used as a reference gene to normalize the samples. Statistical analysis was performed using analysis of variance followed by the post-hoc least significant difference test. "P<0.05, comparison indicated by brackets. Values are presented as the mean \pm standard deviation of 3 independent samples performed in triplicate. LI-cadherin, liver-intestine cadherin; MP, matrix metalloproteinase; shRNA, short hairpin RNA.

Gelatin zymography. The culture supernatant was collected and the total protein concentration of the supernatants of each sample was determined using a Bradford Protein Assay kit (Beyotime Institute of Biotechnology). Culture supernatants containing equal amounts of total protein were mixed with SDS loading buffer (Beyotime Insititute of Biotechnology) and electrophoresed on $10 \%$ denaturing SDS polyacrylamide gels containing $1 \mathrm{mg} / \mathrm{ml}$ gelatin. Following electrophoresis, the gels were soaked in $2.5 \%$ Triton X-100 on a shaker for $1 \mathrm{~h}$, the solution was changed after $30 \mathrm{~min}$ to eliminate SDS. Following incubation in zymogen activation buffer $(50 \mathrm{mM}$ Tris- $\mathrm{HCl} \mathrm{pH} 7.5,0.1 \%$ Triton $\mathrm{X}-100$, $0.02 \% \mathrm{NaN}_{3}, 5 \mathrm{mM} \mathrm{CaCl}_{2}$ and $1 \mu \mathrm{M} \mathrm{ZnCl}_{2}$ ) at $37^{\circ} \mathrm{C}$ for $12 \mathrm{~h}$, the gels were rinsed in distilled water and stained for $5 \mathrm{~h}$ with Coomassie blue R250 (Beyotime Institute of Biotechnology). Gelatinolytic bands were observed as clear zones against the blue background and the intensity of the bands was estimated using ImageJ software, version 1.45 (imagej. nih.gov/ij/). The gelatinase expression level of each sample was determined following a minimum of three independent experiments.

Statistical analysis. All analyses were performed using SPSS software, version 11.5 (SPSS, Inc., Chicago, IL, USA). The mRNA and protein levels were analyzed by one-way analysis of variance followed by a post-hoc least-significant difference test. $\mathrm{P}<0.05$ was considered to indicate a statistically significant difference.

\section{Results}

Silencing of LI-cadherin increases the mRNA level of MMP-2 and MMP-9 in LoVo cells. To investigate the effect of silencing LI-cadherin on the mRNA levels of MMP-2 and MMP-9 in LoVo cells, RT-PCR analysis was performed. The results demonstrated that there was no significant difference between the mRNA levels of MMP-2 in untreated LoVo cells and in LoVo cells stably expressing pU6-control-shRNA $(\mathrm{P}>0.05)$. By contrast, the mRNA level of MMP-2 in LoVo cells expressing pU6-LI-cadherin-shRNA was significantly increased compared with untreated $(\mathrm{P}<0.05)$ and $\mathrm{pU6}$-control-shRNA-expressing LoVo cells $(\mathrm{P}<0.05$; Fig. 1A). Similarly, the mRNA level of MMP-9 did not differ between untreated and LoVo cells stably expressing pU6-control-shRNA ( $\mathrm{P}>0.05)$. However, the mRNA level of MMP-9 was significantly increased in LoVo cells following silencing LI-cadherin compared with untreated and control shRNA-transfected cells ( $\mathrm{P}<0.05$; Fig. 1B).

Silencing of LI-cadherin increases the protein levels and activity of MMP-2 and MMP-9 in LoVo cells. To explore whether the protein expression levels and activity of MMP-2 and MMP-9 were altered following knockdown 
A

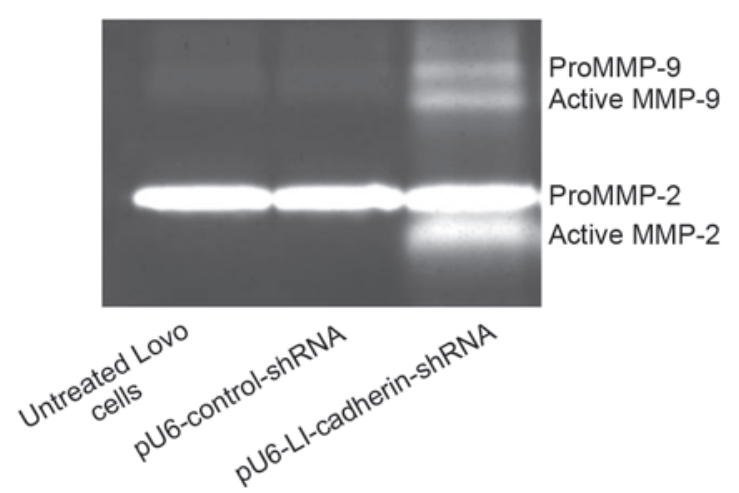

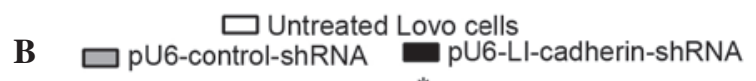

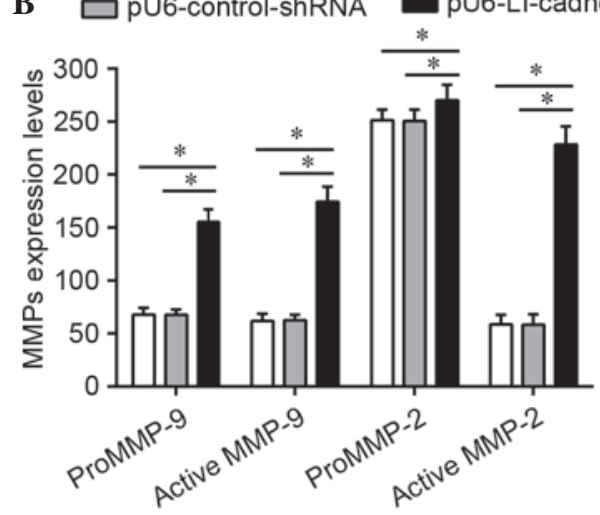

Figure 2. Effects of silencing LI-cadherin on the protein levels and activities of MMP-2 and MMP-9. (A) Gelatin zymographic analysis. (B) Quantification of zymography. Statistical analysis was performed using analysis of variance followed by post-hoc least significant difference test. ${ }^{*} \mathrm{P}<0.05$, comparisons indicated by brackets. Values are presented as the mean \pm standard deviation of 3 independent samples performed in triplicate. LI-cadherin, liver-intestine cadherin; MMP, matrix metalloproteinase; shRNA, short hairpin RNA.

A

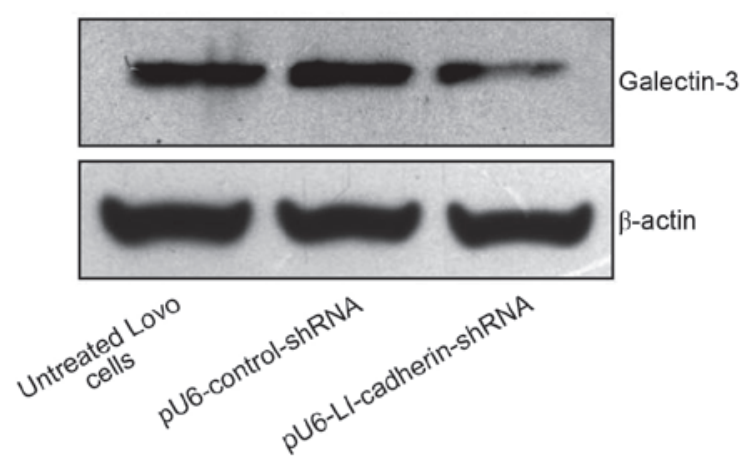

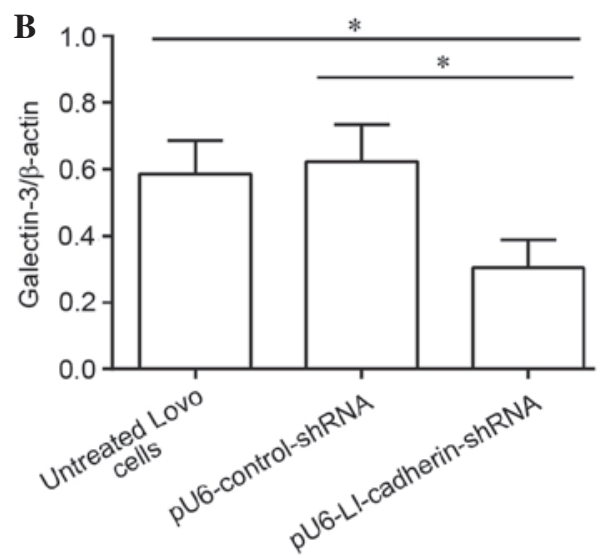

Figure 3. Effect of LI-cadherin knockdown on the protein levels of galectin-3 in LoVo cells. (A) Western blot analysis was performed to detect galectin-3. $\beta$-actin was used as a loading control. (B) Statistical analysis was performed using analysis of variance followed by the post-hoc least significant difference test. ${ }^{*} \mathrm{P}<0.05$, comparisons indicated by brackets. Values are expressed as the ratio of galectin- 3 to $\beta$-actin level and presented as the mean \pm standard deviation of 3 independent samples performed in triplicate. LI-cadherin, liver-intestine cadherin; MMP, matrix metalloproteinase; shRNA, short hairpin RNA.

of LI-cadherin in LoVo cells, a gelatin zymography experiment was performed (Fig. 2). The results of the current study demonstrated that the protein levels of proMMP-2 and -9 , and their active forms were significantly increased in LoVo cells expressing pU6-LI-cadherin-shRNA compared with untreated and control shRNA-transfected LoVo cells $(\mathrm{P}<0.05)$.

Silencing LI-cadherin reduces the protein expression level of galectin-3. Western blot analysis was performed to detect the effect of of LI silencing via transfection with pU6-LI-cadherin-shRNA on the protein levels of galectin-3 in LoVo cells. The protein level of galectin-3 exhibited no significant difference between the untreated cells and cells stably expressing pU6-control-shRNA. By contrast, following knockdown of LI-cadherin, LoVo cells exhibited significantly reduced protein levels of galectin-3 compared with untreated and control shRNA-transfected cells $(\mathrm{P}<0.05$; Fig. 3).

\section{Discussion}

A previous study demonstrated that knockdown of LI-cadherin promotes cell migration, invasion and adhesion (29). However, the mechanisms that mediate these changes remain unclear. The present study demonstrated that silencing of LI-cadherin increases the expression levels (mRNA and protein) and activation of MMP-2 and -9, and downregulates the protein level of galectin-3, which is a substrate for human MMP-2 and MMP-9. Based on the present data, it is proposed that knockdown of LI-cadherin expression facilitates the invasion of cancer cells by degrading ECM components via enhanced expression and activation of MMP-2 and -9, and increases cancer cell adhesion and migration via altered expression of galectin-3.

The MMPs are a tightly regulated family of enzymes that degrade ECM and basement membrane components, thus allowing cancer cells access to subepithelial structures (30). 
MMP-2 and -9, in particular, are important for cleaving major components of the basement membrane, such as type IV collagen. They interact with $\alpha v \beta 3$ integrin, which contributes to collagen degradation, cell migration and cell invasion $(31,32)$. A previous study demonstrated that silencing LI-cadherin promotes cell invasion (29). The present study demonstrated that knockdown of LI-cadherin increased the expression levels and activation of MMP-2 and -9. Thus, it is concluded that LI-cadherin-associated invasion may contribute to LI-cadherin-induced alteration and activation of MMP-2 and -9 .

A previous study demonstrated that galectin-3 (31 kDa) is cleaved by MMP-2 and -9 to generate $22-\mathrm{kDa}$ and $9-\mathrm{kDa}$ fragments $(28,33)$. In the current study, silencing LI-cadherin in LoVo cells significantly increased the mRNA levels of MMP-2 and -9, whereas the protein level of galectin-3 was downregulated under the same conditions. Together these studies suggest that the reduction in the protein levels of galectin-3 (31 kDa) is induced via enhanced cleavage resulting from increased expression levels of MMP-2 and -9 meditated by LI-cadherin.

In the present study, silencing LI-cadherin reduced the protein levels of galectin-3, a protein that is closely involved in tumor cell transformation, migration, invasion and metastasis. A previous study indicates that $\mathrm{Ca}^{2+}$-dependent cell-cell adhesion mediated by LI-cadherin is independent of interaction with cytoplasmic components (10). Thus, it is possible that LI-cadherin inhibits LoVo cell migration and adhesion via galectin-3 in an indirect manner. However, galectin-3 predominantly promotes tumor development in cancer, however, it acts as a tumor-suppressor in certain types of cancer (34). Additionally, Bartolomé et al (7) reported a different mechanism when they investigated the association between LI-cadherin and cell proliferation and adhesion. They demonstrated that cell adhesion, proliferation and liver metastasis were reduced following knockdown of LI-cadherin in KM12 metastatic colorectal cancer cells, and the effects are regulated by interaction between LI-cadherin and $\alpha 2 \beta 1$ integrin. The previous study also observed a significant correlation between LI-cadherin overexpression and poor survival in colorectal cancer, whereas, other studies had previously demonstrated that reduced expression of LI-cadherin is associated with lymph node metastasis (11), or tumor dedifferentiation and poor overall survival (35) based on immunohistochemical analysis. The conflicting results are possibly caused by differences in samples number, the ratio of cancer stage and cell types. The association of LI-cadherin expression with cell adhesion requires further elucidation.

In summary, previous studies have demonstrated that LI-cadherin has an important function in migration, invasion and adhesion $(13,19,29,36)$. LI-cadherin acts via various molecular mechanisms depending on the cancer cell type. In the current study, it was identified that in colorectal cancer cells, there was an association between LI-cadherin, gelatinases and galectin-3, providing insight into the functional regulation of LI-cadherin and a better understanding of the molecular mechanisms of the LI-cadherin. Further study of LI-cadherin may be important to advance the understanding of human cancer progression and developing novel diagnostic markers.

\section{Acknowledgements}

The present study was supported by grants from the National Natural Science Foundation of China (grant nos. 81460462 and 31460696), the Technology Pedestal and Society Development Project of Jiangxi Province (grant no. 20141BBG70040) and the Science Foundation of Educational Department of Jiangxi Province (grant no. 86283702).

\section{References}

1. Bulgakova NA, Klapholz B and Brown NH: Cell adhesion in Drosophila: Versatility of cadherin and integrin complexes during development. Curr Opin Cell Biol 24: 702-712, 2012.

2. Leckband D and Sivasankar S: Cadherin recognition and adhesion. Curr Opin Cell Biol 24: 620-627, 2012.

3. Yan X, Yan L, Liu S, Shan Z, Tian Y and Jin Z: N-cadherin, a novel prognostic biomarker, drives malignant progression of colorectal cancer. Mol Med Rep 12: 2999-3006, 2015.

4. Shapiro L and Weis WI: Structure and biochemistry of cadherins and catenins. Cold Spring Harb Perspect Biol 1: a003053, 2009.

5. van Roy F: Beyond E-cadherin: Roles of other cadherin superfamily members in cancer. Nat Rev Cancer 14: 121-134, 2014.

6. Takamura M, Yamagiwa S, Matsuda Y, Ichida T and Aoyagi Y: Involvement of liver-intestine cadherin in cancer progression. Med Mol Morphol 46: 1-7, 2013.

7. Bartolomé RA, Barderas R, Torres S, Fernandez-Aceñero MJ Mendes M, García-Foncillas J, Lopez-Lucendo M and Casal JI: Cadherin-17 interacts with $\alpha 2 \beta 1$ integrin to regulate cell proliferation and adhesion in colorectal cancer cells causing liver metastasis. Oncogene 33: 1658-1669, 2014.

8. Su MC, Yuan RH, Lin CY and Jeng YM: Cadherin-17 is a useful diagnostic marker for adenocarcinomas of the digestive system. Mod Pathol 21: 1379-1386, 2008.

9. Berndorff D, Gessner R, Kreft B, Schnoy N, Lajous-Petter AM, Loch N, Reutter W, Hortsch M and Tauber R: Liver-intestine cadherin: Molecular cloning and characterization of a novel $\mathrm{Ca}(2+)$-dependent cell adhesion molecule expressed in liver and intestine. J Cell Biol 125: 1353-1369, 1994.

10. Kreft B, Berndorff D, Böttinger A, Finnemann S, Wedlich D, Hortsch M, Tauber R and Gessner R: LI-cadherin-mediated cell-cell adhesion does not require cytoplasmic interactions. J Cell Biol 136: 1109-1121, 1997.

11. Takamura M, Ichida T, Matsuda Y, Kobayashi M, Yamagiwa S, Genda T, Shioji K, Hashimoto S, Nomoto M, Hatakeyama K, et al: Reduced expression of liver-intestine cadherin is associated with progression and lymph node metastasis of human colorectal carcinoma. Cancer Lett 212: 253-259, 2004.

12. Sakamoto N, Oue N, Sentani K, Anami K, Uraoka N, Naito Y, Oo HZ, Hinoi T, Ohdan H, Yanagihara K, et al: Liver-intestine cadherin induction by epidermal growth factor receptor is associated with intestinal differentiation of gastric cancer. Cancer Sci 103: 1744-1750, 2012.

13. Liu QS, Zhang J, Liu M and Dong WG: Lentiviral-mediated miRNA against liver-intestine cadherin suppresses tumor growth and invasiveness of human gastric cancer. Cancer Sci 101: 1807-1812, 2010.

14. Dong WG, Yu QF, Xu Y and Fan LF: Li-cadherin is inversely correlated with galectin-3 expression in gastric cancer. Dig Dis Sci 53: 1811-1817, 2008.

15. Park SS, Kang SH, Park JM, Kim JH, Oh SC, Lee JH, Chae YS, Kim SJ, Kim CS and Mok YJ: Expression of liver-intestine cadherin and its correlation with lymph node metastasis in gastric cancer: Can it predict N stage preoperatively? Ann Surg Oncol 14: 94-99, 2007.

16. Dong W, Yu Q and Xu Y: Altered expression of a Li-cadherin in gastric cancer and intestinal metaplasia. Dig Dis Sci 52: 536-542, 2007.

17. Takamura M, Sakamoto M, Ino Y, Shimamura T, Ichida T, Asakura $\mathrm{H}$ and Hirohashi $\mathrm{S}$ : Expression of liver-intestine cadherin and its possible interaction with galectin-3 in ductal adenocarcinoma of the pancreas. Cancer Sci 94: 425-430, 2003.

18. Fan ZJ, Fang XJ, Wang JX, Xue JF and Zhang Y: Expression of liver-intestine cadherin and its significance in hepatocellular carcinoma. Zhonghua Yi Xue Za Zhi 91: 2546-2548, 2011 (In Chinese). 
19. Ding ZB, Shi YH, Zhou J, Shi GM, Ke AW, Qiu SJ, Wang XY, Dai Z, Xu Y and Fan J: Liver-intestine cadherin predicts microvascular invasion and poor prognosis of hepatitis B virus-positive hepatocellular carcinoma. Cancer 115: 4753-4765, 2009.

20. Chen XT, Du HY, Yuan SF, Wang SM and Li M: Effect of monoclonal antibodies against LI-cadherin on the proliferation of human hepatocellular carcinoma cells. Nan Fang Yi Ke Da Xue Xue Bao 29: 880-883, 2009 (In Chinese).

21. Wang XQ, Luk JM, Garcia-Barcelo M, Miao X, Leung PP, Ho DW, Cheung ST, Lam BY, Cheung CK, Wong AS, et al: Liver intestine-cadherin (CDH17) haplotype is associated with increased risk of hepatocellular carcinoma. Clin Cancer Res 12: 5248-5252, 2006.

22. Wang XQ, Luk JM, Leung PP, Wong BW, Stanbridge EJ and Fan ST: Alternative mRNA splicing of liver intestine-cadherin in hepatocellular carcinoma. Clin Cancer Res 11: 483-489, 2005.

23. Wong BW, Luk JM, Ng IO, Hu MY, Liu KD and Fan ST: Identification of liver-intestine cadherin in hepatocellular carcinoma - a potential disease marker. Biochem Biophys Res Commun 311: 618-624, 2003

24. Ryu KH, Shim KN, Jung SA, Yoo K, Joo YH and Lee JH: Significance of preoperative tissue levels of vascular-endothelial cadherin, liver-intestine cadherin and vascular endothelial growth factor in gastric cancer. Korean J Gastroenterol 60: 229-241, 2012

25. Ko S, Chu KM, Luk JM, Wong BW, Yuen ST, Leung SY and Wong J: Overexpression of LI-cadherin in gastric cancer is associated with lymph node metastasis. Biochem Biophys Res Commun 319: 562-568, 2004.

26. Fortuna-Costa A, Gomes AM, Kozlowski EO, Stelling MP and Pavão MS: Extracellular galectin-3 in tumor progression and metastasis. Front Oncol 4: 138, 2014.

27. Boscher C, Zheng YZ, Lakshminarayan R, Johannes L, Dennis JW, Foster LJ and Nabi IR: Galectin-3 protein regulates mobility of $\mathrm{N}$-cadherin and GM1 ganglioside at cell-cell junctions of mammary carcinoma cells. J Biol Chem 287: 32940-32952, 2012.
28. Ochieng J, Fridman R, Nangia-Makker P, Kleiner DE, Liotta LA, Stetler-Stevenson WG and Raz A: Galectin-3 is a novel substrate for human matrix metalloproteinases-2 and -9 . Biochemistry 33 : 14109-14114, 1994.

29. Yu QF, Dong WG and Ren JL: Knockdown of Li-cadherin increases metastatic behaviors of LoVo cells. J Cancer Res Clin Oncol 136: 1641-1649, 2010.

30. Hadler-Olsen E, Winberg JO and Uhlin-Hansen L: Matrix metalloproteinases in cancer: Their value as diagnostic and prognostic markers and therapeutic targets. Tumour Biol 34: 2041-2051, 2013.

31. Brooks PC, Strömblad S, Sanders LC, von Schalscha TL, Aimes RT, Stetler-Stevenson WG, Quigley JP and Cheresh DA: Localization of matrix metalloproteinase MMP-2 to the surface of invasive cells by interaction with integrin alpha $\mathrm{v}$ beta 3 . Cell 85: 683-693, 1996.

32. Rolli M, Fransvea E, Pilch J, Saven A and Felding-Habermann B: Activated integrin alphavbeta3 cooperates with metalloproteinase MMP-9 in regulating migration of metastatic breast cancer cells. Proc Natl Acad Sci USA 100: 9482-9487, 2003.

33. Ochieng J, Green B, Evans S, James O and Warfield P: Modulation of the biological functions of galectin-3 by matrix metalloproteinases. Biochim Biophys Acta 1379: 97-106, 1998.

34. Song L, Tang JW, Owusu L, Sun M-Z, Wu J and Zhang J: Galectin-3 in cancer. Clin Chim Acta 431: 185-191, 2014.

35. Kwak JM, Min BW, Lee JH, Choi JS, Lee SI, Park SS, Kim J, Um JW, Kim SH and Moon HY: The prognostic significance of E-cadherin and liver intestine-cadherin expression in colorectal cancer. Dis Colon Rectum 50: 1873-1880, 2007.

36. Baumgartner W: Possible roles of LI-Cadherin in the formation and maintenance of the intestinal epithelial barrier. Tissue Barriers 1: e23815, 2013. 